\title{
MAGNETIC NANOPARTICLE LABELING OF CULTURED CANCER CELL LINE WITHOUT TRANSFECTION AGENT
}

\author{
Jong-Kai Hsiao*,†, Chung-Yi Yang*,†, Yiao-Hong Wang ${ }^{\dagger, \ddagger}$, \\ Chen-Wen $\mathrm{Lu}^{\dagger}$, Borade Prajakta Uttam ${ }^{\dagger}$, Hon-Man Liu ${ }^{\dagger}$ \\ and Jaw-Lin Wang*,§ \\ *Institute of Biomedical Engineering \\ National Taiwan University, Taipei, Taiwan \\ ${ }^{\dagger}$ Department of Medical Imaging \\ National Taiwan University Hospital and College of Medicine \\ Taipei, Taiwan \\ ${ }^{\ddagger}$ Institute of Electrical-Engineering \\ National Taiwan University \\ Taipei, Taiwan
}

Accepted 26 May 2008

\begin{abstract}
Magnetic nanoparticle (MNP) labeling of stem cell has been proved its efficacy for cell trafficking. Most of the labeling technique requires mixture of iron oxide nanoparticles and transfection agent. Stem cells with ionic MNP without the aid of transfection agent were labeled previously. The possibility of high efficiency labeling of cultured cancer cell, HeLa cell, by using ionic MNP is proposed. The labeled cell morphology was observed and the intracellular iron content was determined by spectrophotometry. The cell character change was evaluated by flow cytometry where front scattering count and side scattering count (SSC) were recorded. The imaging ability of the labeling method was determined by T2 weighted magnetic resonance (MR) imaging. Labeled MNPs were accumulated at cytoplasm is observed and the iron content of labeled cell could reach $27 \mathrm{pg} /$ cell. There is no cell diameter change but the cell granularity increased according to SSC data from flow cytometry. Under clinical 1.5 T MR imaging, we could detect labeled cells easily were detected at the cell number of $1 \times 10^{5}$. It is concluded that labeling of cancer cell with ionic MNPs without transfection agent is an efficient labeling method which will provide non-invasive imaging method for monitoring cancer behavior.
\end{abstract}

Keywords: Magnetic nanoparticle; Magnetic resonance imaging; HeLa cell; Iron oxide.

\section{INTRODUCTION}

Magnetic nanoparticles (MNPs) composed of iron oxide are widely used as magnetic resonance imaging contrast medium. ${ }^{1}$ The cores of these nanoparticles are made up of either $\mathrm{Fe}_{3} \mathrm{O}_{4}$ or $\mathrm{r}-\mathrm{Fe}_{2} \mathrm{O}_{3} \cdot{ }^{1,2}$ To prevent particle aggregation or precipitation, the particles are coated with either dextran or carboxydextran. ${ }^{3,4}$ Both iron oxide and dextran derivatives are biocompatible

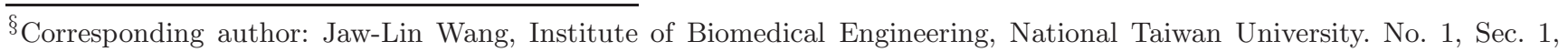
Ren-ai Rd., Taipei, Taiwan. Tel.: +886-2-33665269; Fax: +886-2-33665268; E-mail: jlwang@ntu.edu.tw 
materials which could be degraded safely in the human body. ${ }^{5}$

Clinically, MNPs have been used as liver specific or blood pool MR contrast medium. ${ }^{4,6}$ In addition, it has been used for stem cell labeling. The labeled stem cells could be identified in vivo under MRI. ${ }^{7}$ This technique helps us to understand the fate of stem cells in vivo without damaging the living organism. However, for optimizing the efficiency of stem cell labeling, transfection agent such as protamine sulfate is usually added. ${ }^{8,9}$ There is a debate on the influence of transfection agent on the labeled cells. ${ }^{10}$ Most of the concerns are alteration of differentiation ability of the stem cells. We thus developed a labeling technique by using ionic MNPs instead of non-ionic MNPs. The efficiency is high enough that we can detect labeled stem cells in a single cells level under clinical 1.5 Tesla MRI. ${ }^{11}$

HeLa cells are cervical cancer cell line that has been used widely for investigating cancer biology. ${ }^{12}$ It is recognized by its immortal behavior owing to the telomerase activity. Labeling of HeLa cells with ionic MNPs would help us understand its behavior once if the HeLa cells have been implanted in the living organism. Moreover, it would further prove the cell labeling capacity by using ionic MNPs. Consequently, we investigated the feasibility of labeling HeLa cells with ionic MNPs by analyzing labeling efficacy, cell viability, cell morphology, and Magnetic Resonance (MR) imaging.

\section{MATERIAL AND METHODS Cell Culture and Iron Oxide Treatment}

HeLa cell was purchased from the Culture Collection and Research Center (CCRC, Hsin-Chu, Taiwan). The cells were cultured in Dulbecco's modified Eagle Medium (DMEM) (Cellgro, Herndon, VA, USA), supplemented with $10 \%$ heat-inactivated fetal bovine serum (FBS), penicillin $(50 \mathrm{U} / \mathrm{ml})$, and streptomycin $(0.05 \mathrm{mg} / \mathrm{ml})$. The cells were incubated at $37^{\circ} \mathrm{C}$ in $5 \%$ $\mathrm{CO}_{2}$. For incubation with MNPs, Ferucarbotran, a clinically approved ionic MNPs was added to the culture medium at concentrations of 1,10 or $100 \mu \mathrm{g} \mathrm{Fe} / \mathrm{ml}$ respectively which corresponds to $0.11,1.1$, and 11 times plasma concentration after intravenous administration of Ferucarbotran at suggested dosage. ${ }^{13}$

\section{Iron Content Measurement}

Iron concentration of HeLa cell was determined as described in Refs. 13 and 14. Briefly, $1 \times 10^{5}$ SPIO labeled human HeLa were lyzed using 1\% sodium dodecyl sulfate (SDS). The solution was then examined spectrophotometrically at $248.3 \mathrm{~nm}$. The iron concentration was determined by comparing the absorption value of each sample with six Ferucarbotran containing standards with iron concentration ranging from 5000 to $2,000,000 \mu \mathrm{g} \mathrm{Fe} / \mathrm{ml}$.

\section{Morphology and Particle Uptake Efficiency Assay}

The cells were imaged using an inverted microscope (Nikon Eclipse TS100, Tokyo, Japan) at $200 \times$ magnification. Prussian blue staining was used for localization of the intracellular iron oxide as described in Ref. 15. Flow cytometry (FACS Calibur, Becton Dickinson, San Jose, CA, USA) was applied for the determination of granularity change and cell diameter between MNPs treated and non-treated groups. ${ }^{16}$ Briefly, macrophages were collected by measuring side scattering counts (SSC) and front scattering counts (FSC). For each group of macrophages, 10,000 counts were measured and the results were graphed with the assistance of computer software (CellQuest, Becton Dickinson, San Jose, CA, USA).

\section{MRI Image}

The confirmation of MNPs loading was further investigated by MR imaging as described in Ref. 17. HeLa cells were treated with $0,1,10$ or $100 \mu \mathrm{g} \mathrm{Fe} / \mathrm{ml}$ of MNPs for 1, 4, and $18 \mathrm{~h}$ and then harvested, centrifuged in a $200 \mu \mathrm{l}$ test tube. Up to $1 \times 10^{5}$ cells were collected for MR imaging. These cell samples were positioned in the water bath, and then placed into 1.5 Tesla clinical MRI system equipped with a eight channel head colid (Signa Excite, GE Healthcare NJ, USA) and scanned under T2 weighted gradient echo pulse sequences $(\mathrm{TR}=550, \mathrm{TE}=5$, $\mathrm{FA}=15^{\circ}, \mathrm{FOV}=16 \mathrm{~cm} \times 8 \mathrm{~cm}$, resolution $=256 \times 192$, slice thickness $=1.4 \mathrm{~mm}$, spacing $=0.3 \mathrm{~mm}, \mathrm{NEX}=3$ ). The acquired images were analyzed by the image workstation provided by the vendor.

\section{RESULTS}

Prussian blue stain of HeLa cells revealed abundant deep blue granules in the cytoplasm of cells treated with $100 \mu \mathrm{g} \mathrm{Fe} / \mathrm{ml}$ MNPs and could also be found at lesser degree in cells exposed to MNPs at the concentration of $10 \mu \mathrm{g} \mathrm{Fe} / \mathrm{ml}$. The cell nucleus is not stained. The blue staining could not be found in cells exposed to MNPs at the concentration of $0.1 \mu \mathrm{g} \mathrm{Fe} / \mathrm{ml}$ (Fig. 1). 


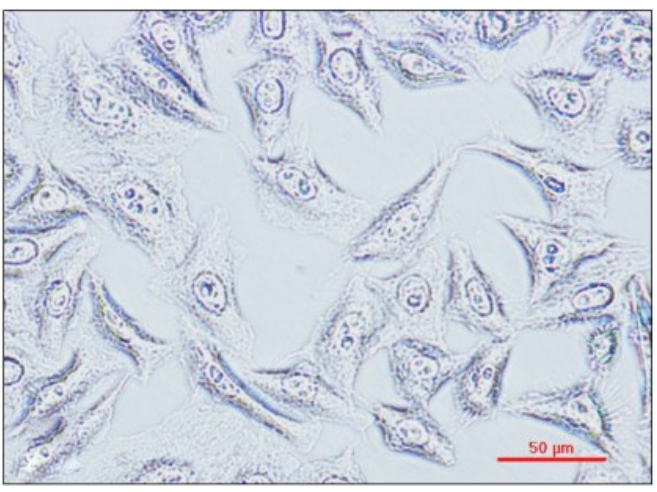

(A)

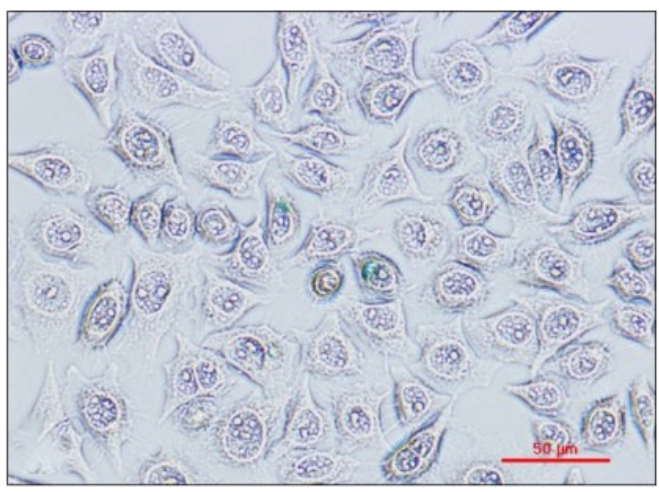

(B)

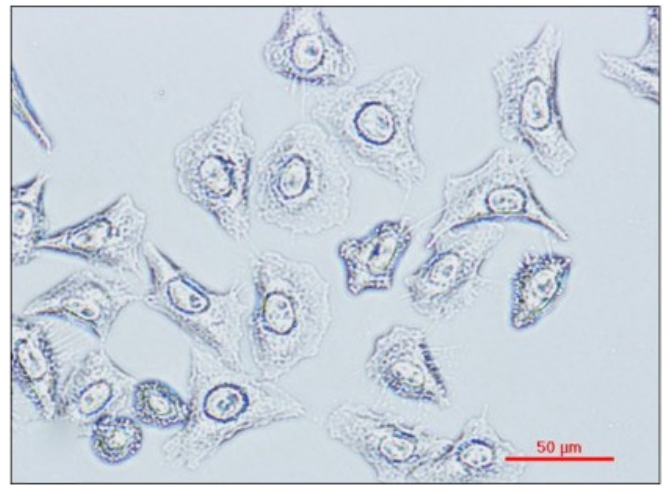

(C)

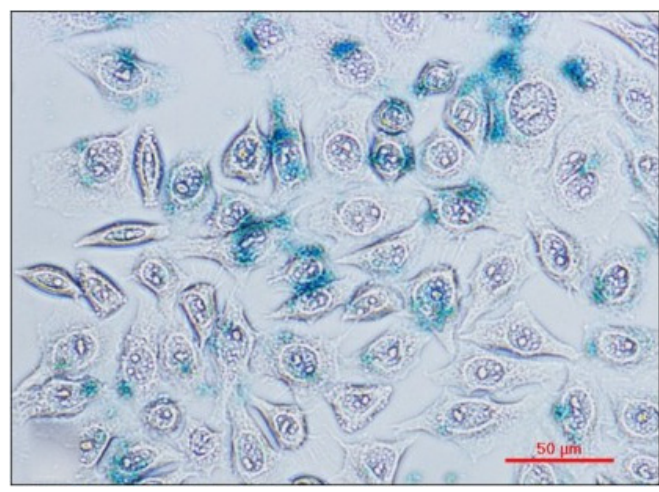

(D)

Fig. 1 Microscopic view of HeLa cells labeled with ionic MNPs at $0 \mu \mathrm{g} \mathrm{Fe} / \mathrm{ml}$ (A), $1 \mu \mathrm{g} \mathrm{Fe} / \mathrm{ml}$ (B), $10 \mu \mathrm{g} \mathrm{Fe} / \mathrm{ml}$ (C) and $100 \mu \mathrm{g} \mathrm{Fe} / \mathrm{ml}$ (D) for $18 \mathrm{~h}$. The cells were stained with Prussian blue and the images were taken at the magnification of $20 \times$.

For quantification of MNPs uptake into cells, HeLa cells exposed to 1, 10, and $100 \mu \mathrm{g} \mathrm{Fe} / \mathrm{ml}$ of MNPs were further analyzed for their iron content. We observed that the time and dose dependent manner of iron content increase. The iron content inside the cell is richest in cells exposed to $100 \mu \mathrm{g} \mathrm{Fe} / \mathrm{ml}$ of MNPs for $18 \mathrm{~h}$. The iron content reached $27 \mathrm{pg} /$ cell, which is 1.9 times higher compared to cells treated for only $1 \mathrm{~h}$ (Fig. 2).

The cell behavior changes were determined by flow cytometry. The FSC versus SSC was measured and the distribution indicated the cell morphology and the cell debris. There is no significant increase in cell debris in each groups compared with control group where no ionic MNPs were added (Fig. 3).

The pattern of histograms of FSC was measured as a means for evaluating cell morphology. There is no evidence of cell size change in all of the groups which was evidenced by similar count peak at the same level (Fig. 4).

The pattern of SSC was shifted to left side when the cells were treated with higher concentration of ionic MNPs and longer exposure time (Fig. 5(A)). The pattern could be demonstrated more clearly at merged
Iron content of labeled HeLa cells

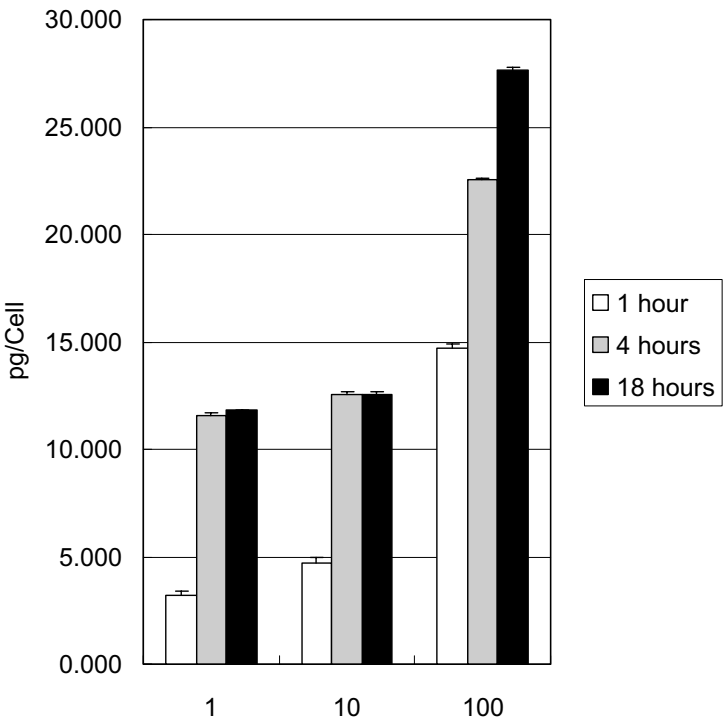

Nanoparticle concentration $(\mu \mathrm{g} \mathrm{Fe} / \mathrm{mL})$

Fig. 2 Photospectrometric analysis of iron content of HeLa cells labeled with different concentration of ionic MNPs with different incubation time. The concentration is 1,10 , and $100 \mu \mathrm{g} \mathrm{Fe} / \mathrm{ml}$ and the incubation time varied from 1,4 to $18 \mathrm{~h}$. 
MNPs concentration ( $\mu \mathrm{g} \mathrm{Fe} / \mathrm{mL}$ )

Exposure Time 1 hour

4 hours

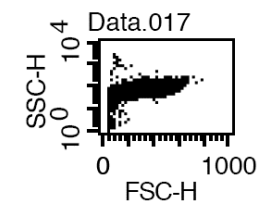

18 hours
0
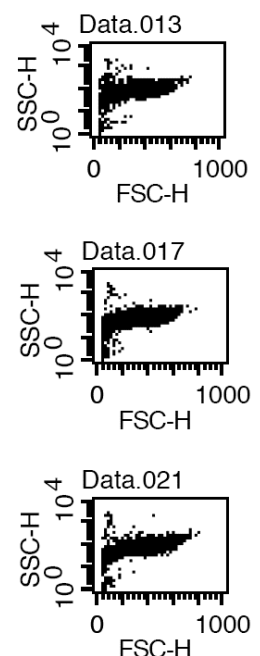

1
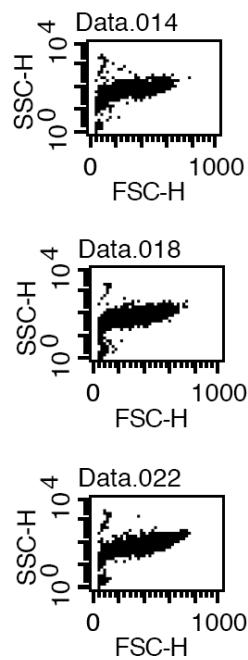

10
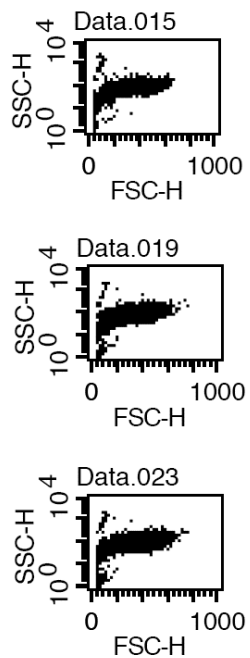

100
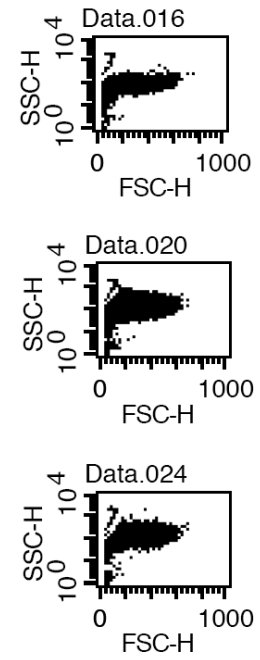

Fig. 3 Flow cytometry analysis of ionic MNPs labeled HeLa cells at 1, 4, and $18 \mathrm{~h}$ with different MNPs concentration from 0,1 , 10 to $100 \mu \mathrm{g} \mathrm{Fe} / \mathrm{ml}$. The scattered plots represented the cell distribution at different size and granularity. The cell debris and dead cells are represented as small clusters of dots at left lower corner of each plot.

\section{MNPs Concentration ( $\mu \mathrm{g} \mathrm{Fe} / \mathrm{mL})$}
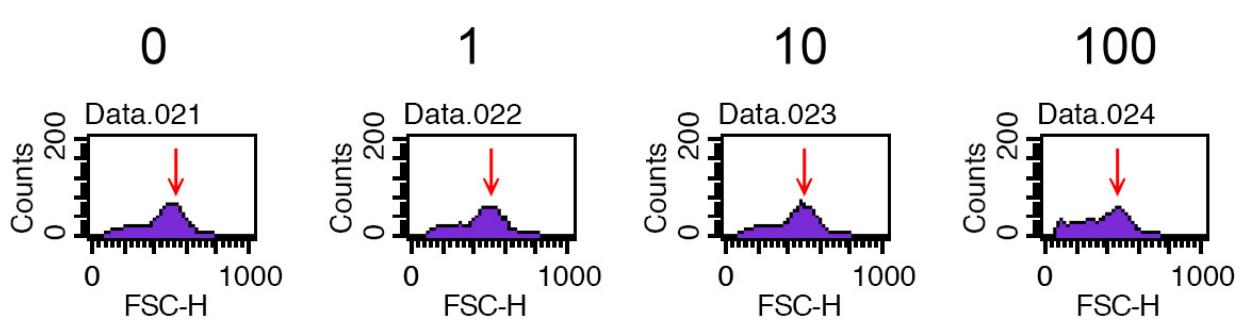

Fig. 4 Cell diameter measurement by histograms of FSC of ionic MNPs labeled HeLa cells for $18 \mathrm{~h}$. The red arrows indicate the peak number of cell diameter. The cells were exposed to ionic MNPs at $0,1,10$, and $100 \mu \mathrm{g} \mathrm{Fe} / \mathrm{ml}$, respectively.

plot where HeLa cells were exposed to MNPs for $18 \mathrm{~h}$ at different MNPs concentration (Fig. 5(B)).

The cells were further investigated for its labeling ability by directly scanned under $1.5 \mathrm{~T}$ clinical MRI. There is marked signal intensity drop in cells treated with $100 \mu \mathrm{g} \mathrm{Fe} / \mathrm{ml}$ MNPs at $18 \mathrm{~h}$. The signal intensity drop also revealed incubation dose and time-dependent manner. There is no signal intensity change at control group, whereas the signal intensity drop could be observed in cells treated from 10 to $100 \mu \mathrm{g} \mathrm{Fe} / \mathrm{ml}$ when the incubation time reaches $18 \mathrm{~h}$ (Fig. 6).

\section{DISCUSSION}

Labeling of cells with MNPs for cell trafficking provide a non-invasive method for monitoring cell implantation.
However, transfection agent such as protamine sulfate is usually needed for facilitating cell labeling. We previously reported a new method for labeling human mesenchymal stem cells without transfecting agent. Using this technique we can observe labeled cell at single cell level. ${ }^{11}$ We proved in this paper that the same labeling method could be applied into cancer cells. Besides, the labeling efficiency is comparable in HeLa cell which has $27 \mathrm{pg} \mathrm{Fe} /$ cell compared to human mesenchymal stem cells that has $23.4 \mathrm{pg} \mathrm{Fe} / \mathrm{cell}$ in our previous study. This finding further support the application ability of this labeling method.

We reported that the ingested MNPs will be transported to membrane bound intracellular organelle which was supposed to be lysosomes. ${ }^{18}$ This phenomenon also supports the finding of SSC increase in cells with MNPs uptake. This measuring method would 

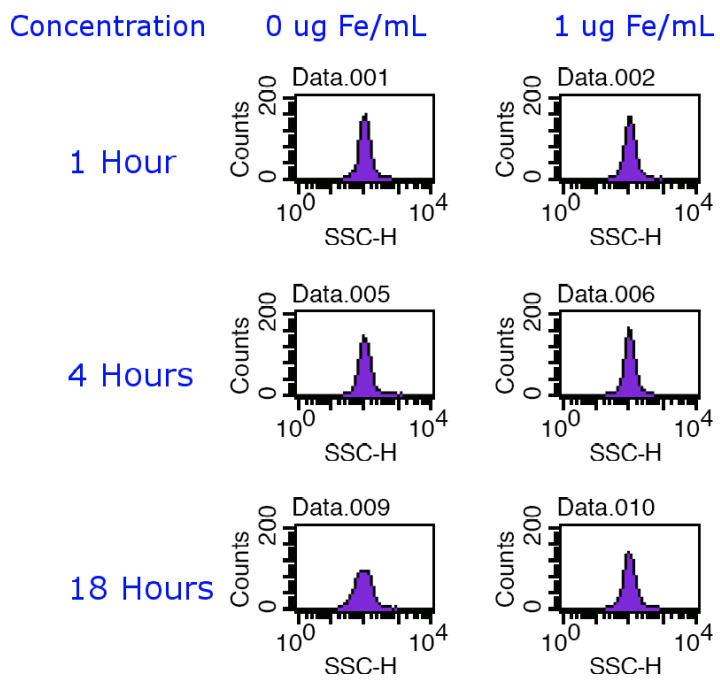

(A)
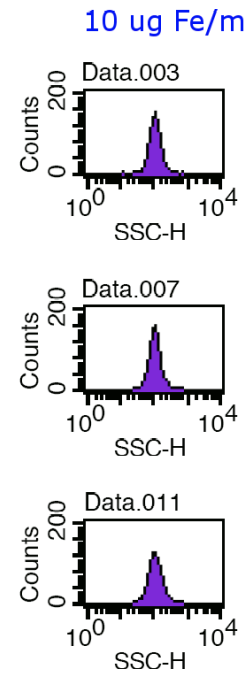
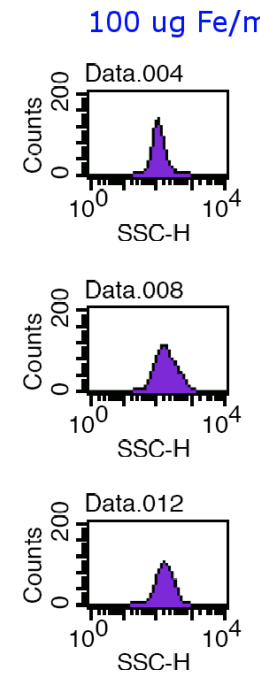
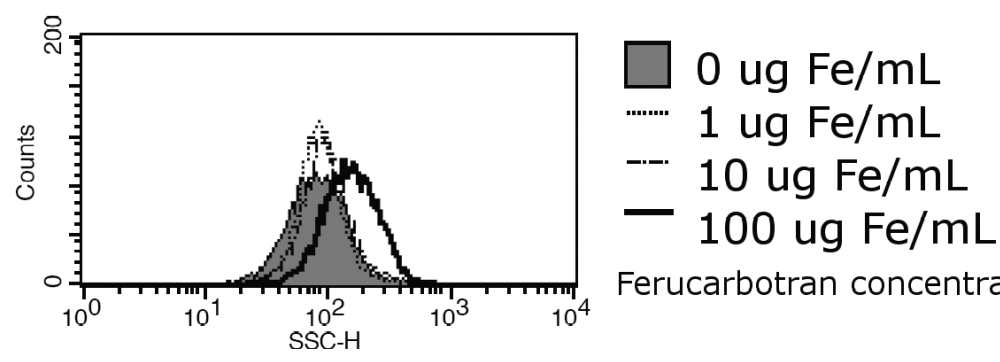

Ferucarbotran concentration

(B)

Fig. 5 (A) Cell granularity measured by histograms of SSC at different concentrations of ionic MNPs and exposure time interval. The concentration was $0,1,10$, and $100 \mu \mathrm{g} \mathrm{Fe} / \mathrm{ml}$, respectively, whereas the exposure time was 1 , 4, and $18 \mathrm{~h}$. (B) Merged histogram revealed cell granularity change at different ionic MNPs concentration. These cells were exposed to MNPs for $18 \mathrm{~h}$.

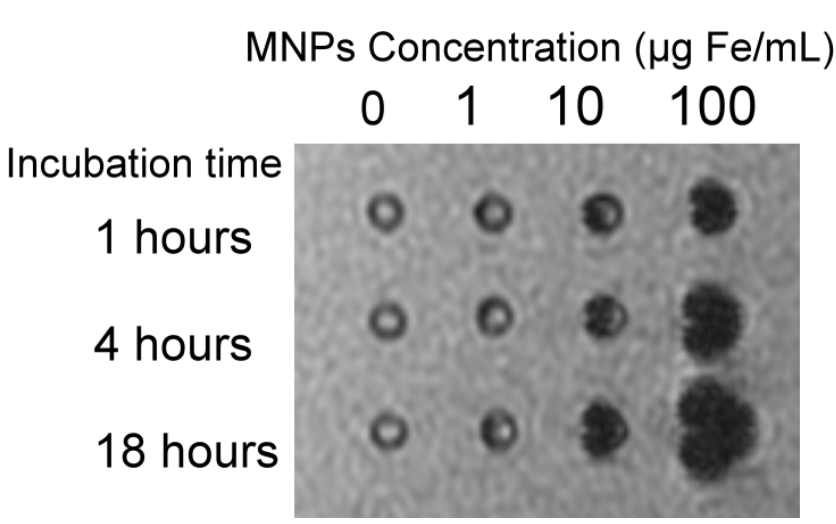

Fig. 6 Cross-sectional T2 weighted MR image of test tubes filled with HeLa cells labeling with ionic MNPs at different concentration and different exposure duration. The concentration was $0,1,10$, and $100 \mu \mathrm{g} \mathrm{Fe} / \mathrm{ml}$ and the MNPs exposure time is 1 , 4 , and $18 \mathrm{~h}$.

be a fast, robust technique to analyze MNPs labeling efficiency since the MNPs attached to the cell membrane will not be detected.

We previously noted that the iron content of the macrophage cell was correlated with labeling efficiency proved by flow cytometry and MRI signal intensity change. ${ }^{18}$ The same correlation could be found in cancer cells. Labeling cancer cells with MNPs have potential benefits in the study of cancer biology. First, it provides us a non-invasive method for monitoring cancer invasion. Second, at the assistance of high resolution MRI, single cancer cell could be detected and be monitored for cancer cell migration, chemotaxis, and metastasis. Third, it is known that cancer cells will interact with adjacent cells such as macrophages. ${ }^{19}$ And we just developed $\mathrm{T} 1$ contrast nanorods. ${ }^{20}$ By labeling these two kinds of cells with either T1 or T2 contrast particle, the interaction between these cells could be observed in living organism, which work could only partially be done by intravital microscopy.

Although we proved the labeling efficiency of ionic MNPs in cancer cells, the uptake mechanism, and its potential effect toward cancer cells is not fully understand. The MNPs uptake pathway was proposed to be clathrin receptor related, consequently, future studies by different uptake inhibitor assay should be analyzed. ${ }^{17}$ 
It was reported that the duration of MNPs labeled stem cells could last up to months. ${ }^{21}$ However, cancer cells proliferate rapidly and the intracellular MNPs might be divided rapidly. ${ }^{19}$ It would be clinical significant to know how long the MNPs could be detected in these cancer cells.

It is proved that no cell differentiation change or viability change after ionic MNPs labeling in human mesenchymal stem cells. ${ }^{11}$ However, the cell behavior change should be further investigated since the cancer cell has different cell behavior including rapid proliferation, migration, and invasion compared to stem cells. ${ }^{22}$ Understanding these effects might have benefits in the treatment of malignancy.

\section{CONCLUSION}

We have developed high efficiency labeling method and imaging ability of HeLa cell, one kind of cancer cell by using ionic MNPs without transfecting agent. The optimum labeling efficiency was incubation at the concentration of $100 \mu \mathrm{g} \mathrm{Fe} / \mathrm{ml}$ for 18 hours. This method will provide us the opportunity for studying cancer biology in living animal by clinical MR imaging facility.

\section{REFERENCES}

1. Moghimi SM, Hunter AC, Murray JC, Nanomedicine: Current status and future prospects, FASEB J 19(3):311-330, 2005.

2. Oude Engberink RD, van der Pol SMA, Dopp EA, de Vries HE, Blezer ELA, Comparison of SPIO and USPIO for in vitro labeling of human monocytes: MR detection and cell function, Radiology 243(2):467-474, 2007.

3. Chouly C, Pouliquen D, Lucet I, Jeune JJ, Jallet P, Development of superparamagnetic nanoparticles for MRI: Effect of particle size, charge and surface nature on biodistribution, $J$ Microencaps 13(3):245-255, 1996.

4. Reimer P, Balzer T, Ferucarbotran (Resovist): A new clinically approved RES-specific contrast agent for contrast-enhanced MRI of the liver: Properties, clinical development, and applications, Euro. Radiol. 13(6):1266-1276, 2003.

5. Arbab AS, Liu W, Frank JA, Cellular magnetic resonance imaging: Current status and future prospects, Expert Rev Med Dev 3(4):427-439, 2006.

6. Bremer C, Allkemper T, Baermig J, Reimer P, RESspecific imaging of the liver and spleen with iron oxide particles designed for blood pool MR-angiography, J Mag Res Imaging 10(3):461-467, 1999.

7. Kraitchman DL, Heldman AW, Atalar E, Amado LC, Martin BJ, Pittenger MF, Hare JM, Bulte JWM, In vivo magnetic resonance imaging of mesenchymal stem cells in myocardial infarction, Circulation 107(18):2290-2293, 2003.
8. Arbab AS, Wilson LB, Ashari P, Jordan EK, Lewis BK, Frank JA, A model of lysosomal metabolism of dextran coated superparamagnetic iron oxide (SPIO) nanoparticles: Implications for cellular magnetic resonance imaging, NMR Biomed 18(6):383-389, 2005.

9. Arbab AS, Frenkel V, Pandit SD, Anderson SA, Yocum GT, Bur M, Khuu HM, Read EJ, Frank JA, Magnetic resonance imaging and confocal microscopy studies of magnetically labeled endothelial progenitor cells trafficking to sites of tumor angiogenesis, Stem Cells 24(3):671-678, 2006.

10. Arbab AS, Yocum GT, Rad AM, Khakoo AY, Fellowes V, Read EJ, Frank JA, Labeling of cells with ferumoxides-protamine sulfate complexes does not inhibit function or differentiation capacity of hematopoietic or mesenchymal stem cells, NMR Biomed 18(8):553-559, 2005.

11. Hsiao JK, Tai MF, Chu HH, Chen ST, Li H, Lai DM, Hsieh ST, Wang JL, Liu HM, Magnetic nanoparticle labeling of mesenchymal stem cells without transfection agent: Cellular behavior and capability of detection with clinical $1.5 \mathrm{~T}$ magnetic resonance at the single cell level, Mag Res Med 58(4):717-724, 2007.

12. Lai CW, Wang YH, Lai CH, Yang MJ, Chen CY, Chou PT, Chan CS, Chi Y, Chen YC, Hsiao JK, Iridium-complex-functionalized $\mathrm{Fe}_{3} \mathrm{O}_{4} / \mathrm{SiO}_{2}$ core/shell nanoparticles: A facile three-in-one system in magnetic resonance imaging, luminescence imaging, and photodynamic therapy, Small 4(2):218-224, 2008.

13. Metz S, Bonaterra G, Rudelius M, Settles M, Rummeny EJ, Daldrup-Link HE, Capacity of human monocytes to phagocytose approved iron oxide MR contrast agents in vitro, Euro Radiol 14(10):1851-1858, 2004.

14. Matuszewski L, Persigehl T, Wall A, Schwindt W, Tombach B, Fobker M, Poremba C, Ebert W, Heindel $\mathrm{W}$, Bremer C, Cell tagging with clinically approved iron oxides: Feasibility and effect of lipofection, particle size, and surface coating on labeling efficiency, Radiology 235(1):155-161, 2005.

15. Arbab AS, Yocum GT, Kalish H, Jordan EK, Anderson SA, Khakoo AY, Read EJ, Frank JA, Efficient magnetic cell labeling with protamine sulfate complexed to ferumoxides for cellular MRI, Blood 104(4):1217-1223, 2004.

16. Hsiao J-K, Tai M-F, Yang C-Y, Chen S-T, Wang J-L, $\mathrm{Ku} \mathrm{H}-\mathrm{C}$, Liu H-M, Comparison of micrometer and nanometer sized magnetic particles for cell labeling, Magnetics, IEEE Trans 43(6):2421-2423, 2007.

17. Lu CW, Hung Y, Hsiao JK, Yao M, Chung TH, Lin YS, Wu SH, Hsu SC, Liu HM, Mou CY, Yang CS, Huang DM, Chen YC, Bifunctional magnetic silica nanoparticles for highly efficient human stem cell labeling, Nano Lett 7(1):149-154, 2007.

18. Hsiao JK, Tai MF, Lee YC, Yang CY, Wang HY, Liu HM, Fang JS, Chen ST, Labeling of cultured macrophages with novel magnetic nanoparticles, J Mag Mag Mater 304(1):e4-e6, 2006.

19. Chen JJW, Lin YC, Yao PL, Yuan A, Chen HY, Shun CT, Tsai MF, Chen CH, Yang PC, Tumor-associated macrophages: The double-edged sword in cancer progression, J Clin Oncol 23(5):953-964, 2005. 
20. Tsai CP, Hung Y, Chou YH, Huang DM, Hsiao JK, Chang C, Chen YC, Mou CY, High-contrast paramagnetic fluorescent mesoporous silica nanorods as a multifunctional cell-imaging probe, Small 4(2):186-191, 2008.

21. Magnitsky S, Watson DJ, Walton RM, Pickup S, Bulte JWM, Wolfe JH, Poptani H, In vivo and ex vivo MRI detection of localized and disseminated neural stem cell grafts in the mouse brain, Neuroimage 26(3):744-754, 2005.

22. Hsiao J-K, Law B, Weissleder R, Tung C-H, In-vivo imaging of tumor associated urokinase-type plasminogen activator activity, J Biomed Opt 11(3):034013034015, 2006. 